
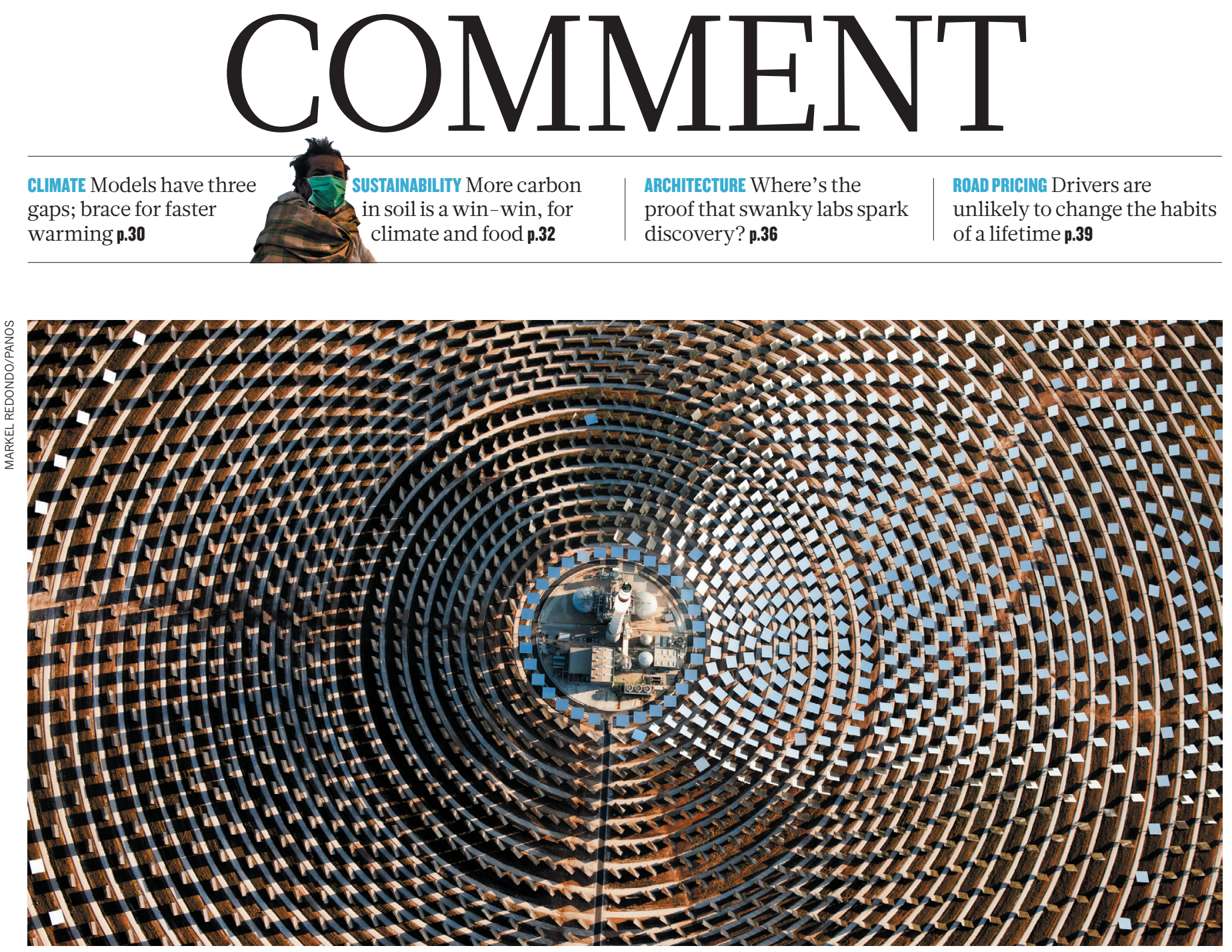

The Gemasolar Thermosolar Plant in Andalusia, Spain.

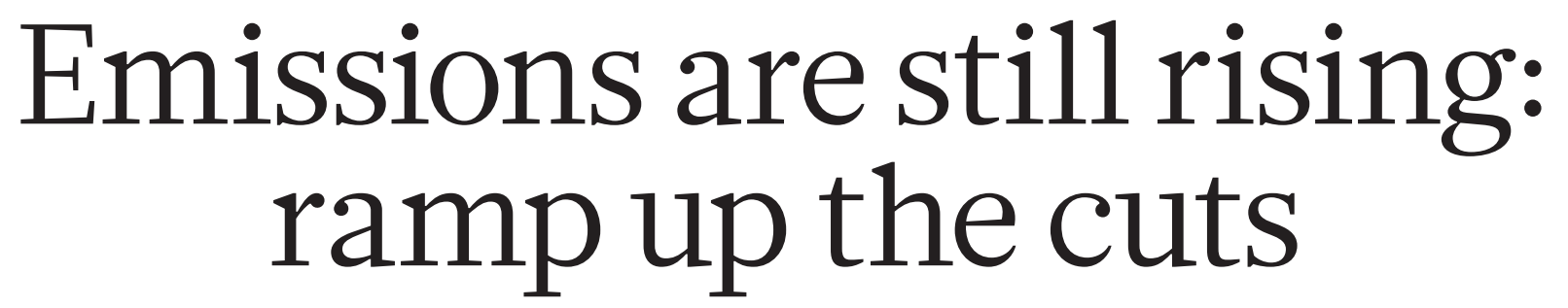
With sources of renewable energy spreading fast, all sectors can do more to decarbonize the world, argue Christiana Figueres and colleagues.

$\mathrm{R}$ epresentatives of 190 nations gather this week to review progress at the annual United Nations climate talks. They face a daunting reality: carbon dioxide emissions from fossil fuels are rising again.

Global $\mathrm{CO}_{2}$ emissions are projected to go up in 2018 by more than $2 \%$ (ref. 1). In 2017 , they increased by $1.6 \%$, having flattened out between 2014 and 2016. The reasons? The use of oil and gas keeps growing, and some countries are still using coal to fuel much of their economic growth (see 'Rising pressures').

The UN meetings, this year in Katowice, in the heart of Poland's coalfields, constitute a checkpoint. The Paris climate agreement was adopted in 2015 - when nations signed up to limit global warming to well below $2{ }^{\circ} \mathrm{C}$, and to strive for $1.5^{\circ} \mathrm{C}$. The first formal revisions of national emissions-reduction targets are in 2020.

To get back on track, the revised targets must be more ambitious than those pledged in 2015. As we argued last year in Nature ${ }^{2}$, global $\mathrm{CO}_{2}$ emissions must start to fall by 2020 if we are to meet the temperature goals of the Paris agreement.

Every year of rising emissions puts economies and the homes, lives and livelihoods of billions of people at risk. It commits us to the effects of climate change for centuries to come. Already, the terrible impacts of $1{ }^{\circ} \mathrm{C}$ of warming above pre-industrial levels are evident. Disasters triggered by weather and climate in 2017 cost the global economy US\$320 billion, and around 10,000 lives were lost (see go.nature.com/2fldcjy). The full costs of 2018's disasters have yet to be tallied - including Typhoon Mangkhut, hurricanes Florence and Michael, and the heatwaves and wildfires that have ravaged swathes of Europe and the United States. These events are likely to contribute to an exponential rise in damages, amounting to some $\$ 2.2$ trillion over the past two decades (see go.nature.com/2r2jyy6). 
When it comes to rises in global average temperature, every fraction of a degree matters. A report published in October by the Intergovernmental Panel on Climate Change (IPCC) projected devastating impacts at $2{ }^{\circ} \mathrm{C}$. These include the loss of almost all the world's coral reefs, and extreme, life-threatening heatwaves that could affect more than one-third of the world's population ${ }^{3}$. Limiting warming to $1.5^{\circ} \mathrm{C}$ will significantly lessen those impacts.

So how can we remain optimistic? A lowcarbon world is hard to imagine, yet change often follows when we shift our vision of what is possible.

\section{REASONS FOR OPTIMISM}

Already, we have achieved things that seemed unimaginable a decade ago. The 2015 Paris agreement is a good example. When the 2009 climate summit in Copenhagen failed to deliver a global framework for addressing climate change, almost everyone thought it was impossible to do so. Yet over the next six years, thousands of people and institutions made the implausible plausible.

The same is true of decarbonizing the economy by 2050 . That goal seems far-fetched today because we are anchored in the highcarbon technologies and economic constructs of the twentieth century. But collectively, we are lifting that anchor and charting a course for a different tomorrow. Here's how.

Key technologies are on track. The world is quickly and irrevocably moving towards a clean, cheap and reliable energy system. Over the past decade, the costs of generating solar energy have plummeted by $80 \%$. Morocco, Mexico, Chile and Egypt are producing solar power for 3 US cents or less per kilowatt hour - cheaper than natural gas.

Installations are growing. Today, more than $50 \%$ of new capacity for generating electricity is renewable, with wind and solar doubling every 4 years ${ }^{4}$. In developing countries, renewables now account for the majority of all new power generation, a remarkable turnaround from just a decade ago. If these trends continue, renewables will produce half of the world's electricity by 2030 .

Coal is being priced out. A record number of US coal-fired power plants will be retired this year, even relatively new ones. In October, the World Bank declined to finance a 500-megawatt coal-fired power plant in Kosovo - the last coal project in the bank's pipeline. The bank's lending rules require it to "go with the lowest cost option, and renewables have now come below the cost of coal", according to its president (see go.nature. com/2du6mxr).

However, the electricity grid will not be completely transformed until renewables are able to deliver continuous power. Large batteries that can store and smooth out energy supplies are becoming economical faster than expected. For example, a year ago, the state of South Australia paired a Tesla battery facility with a local wind farm. By storing power for when demand is highest, the system has already repaid nearly one-third of its upfront capital costs of Aus $\$ 90.6$ million (US $\$ 65.8$ million). The costs of battery storage are expected to halve by 2030 (see go.nature.com/2daiwdt).

By 2040, energy-storage systems should be capable of handling $7 \%$ of the world's total installed power capacity (1,000 gigawatts), supporting even more solar and wind installations. Big batteries will spread beyond utilities, into energy storage for rooftop solar panels, for example. This will allow developing regions to leapfrog the need for fossil-fuel power plants and conventional distribution grids, just as mobile phones overtook landlines.

Advances in battery technology are also propelling wide uptake of electric vehicles. A rarity ten years ago, today there are three million globally on our roads. Plug-in car sales were up by $66 \%$ in the first half of this year, compared with 2017. Although electric vehicles represent a small fraction of the 80 million cars sold worldwide last year, that will soon change. Norway, France, the United Kingdom, the Netherlands and India have set deadlines for stopping the sale of new cars that are not electric (Norway's is 2025). Most major car manufacturers have announced either a complete shift to electric vehicles or plans for a transition. In 2016, the Organization of the Petroleum Exporting Countries (OPEC) said there would be 46 million electric vehicles by 2040; now it predicts there will be 253 million by that date (see go.nature.com/2qjaaoj).

Abating air pollution is another powerful driver of change. Globally, air pollution contributes to seven million premature deaths every year - from cardiovascular disease, ischaemic heart disease, stroke, chronic obstructive pulmonary disease and lung cancer. People are becoming less tolerant of particulate and noxious-gas emissions from coal plants, factories and cars. China has closed coal-fired power plants in and near cities and has limited diesel-engine emissions. Pollution levels in Beijing have fallen by $35 \%$ over 5 years, but still have a long way to go. India has nine of the world's ten most polluted cities, according to the World Health Organization. The country's target is to reduce air pollution in 100 cities by $20-30 \%$ by 2024 .

Heavy industry is also evolving. The Energy Transitions Commission announced last month that chemicals, steel and cement can reach net zero emissions by mid-century at a cost of less than $0.5 \%$ of global gross domestic product (GDP), with a marginal impact on living standards $s^{5}$.

Subnational action is booming. Three years after the Paris agreement, the political landscape has shifted markedly. In some countries, nationalistic impulses are affecting domestic and international policy, threatening the cooperative, multilateral spirit with which the Paris treaty was forged. For example, the federal US government has signalled its intent to withdraw from the agreement - although it cannot formally do so until 2020. Brazil's new administration has expressed doubts about that country's previously ambitious participation. Climate-sceptic voices have re-emerged in Australia.

Yet support for climate action remains strong in cities, regional governments and the private sector. Globally, more than 9,000 cities and municipalities from 128 countries, representing $16 \%$ of the world's population, have reiterated their commitment to the Paris agreement through the Global Covenant of Mayors. So have 245 state and regional bodies from 42 countries, which are home to $17.5 \%$ of the global population ${ }^{6}$. Most US citizens live in a jurisdiction that still supports the Paris goals. If all of these US cities, states and companies stick to their emissions-reduction pledges, they could put the country within striking distance of the Paris commitment made by the Obama administration, irrespective of current federal action.
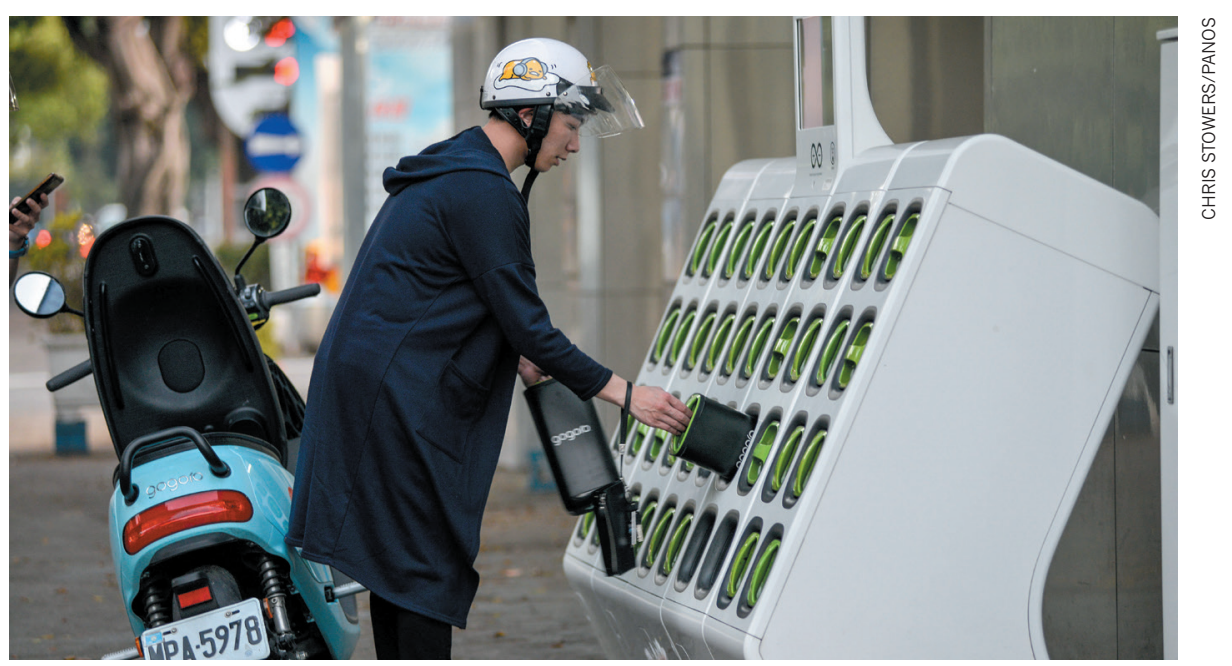

A rider swaps scooter batteries at a roadside facility in Taiwan. 
Boards of directors, presidents of central banks, investors and insurers are increasingly concerned about the economic risks of climate change and the threat to health, water, land and biodiversity resources worldwide. As many as 6,225 companies headquartered in 120 countries have pledged to contribute to the Paris goals ${ }^{6}$, representing $\$ 36.5$ trillion in revenue - more than the combined GDP of the United States and China (see go.nature.com/2aphgjs). These firms understand that the agreement is likely to bring $\$ 26$ trillion in economic benefits by 2030, including 65 million jobs in the booming low-carbon economy.

Carbon pricing is on the rise. In 2017, 1,400 multinational companies were factoring a price on carbon pollution into their business plans - an eightfold rise since 2014 (see go.nature.com/2p9osnb). Nearly one-quarter of the 155 companies that have committed to switching to solely renewable energy through the RE100 initiative are already getting $95 \%$ of their power from clean sources. And close to 500 companies have recognized the business opportunity of setting 'science-based targets' for their emissions reductions.

In 2017, more than 100 members of the Compact of States and Regions reported average reductions in emissions of $8.5 \%$. Twelve members achieved a $20 \%$ reduction or more (see go.nature.com/2aphgjs). Global emissions could be cut by one-third by 2030 compared to current national policy pathways, if ambitious initiatives such as the Under2 Coalition, RE100, C40 and the Global Covenant of Mayors all meet their goals.

Bolder Paris targets. Whereas some parties to the Paris agreement are backsliding, many others are signalling their intention to be more ambitious. The agreement's five-year cycle enables a gradual ratcheting up of effort, and bolder targets will be easier to achieve thanks to the market forces noted previously.

China, India and the European Union are setting the pace. These regions represent $40 \%$ of global carbon emissions. They are set to achieve more than they agreed in the first round. Their leaders can step up and announce even bolder programmes at the UN summit to review the Paris commitments in September 2019.

Leaders of smaller countries with big plans for a safer climate can do the same. In November, the Marshall Islands, a member of the Climate Vulnerable Forum, became the first country to submit a new, more ambitious climate target to the UN.

Twenty-two other countries, from Argentina to the United Kingdom, have declared that they will explore the possibility of strengthening their Paris pledges before 2020. Chile announced in February that it would phase out coal completely. And this September, four nations joined the Carbon Neutrality Coalition, bringing the total to 19. Including

\section{RISING PRESSURES}

Carbon dioxide emissions are growing again after pausing for a few years. Renewable sources of power are just beginning to replace fossil fuels, as their costs become competitive.

\section{EMISSIONS ARE STILL INCREASING}

China and India still rely heavily on coal; the United States and the European Union are slowly decarbonizing.

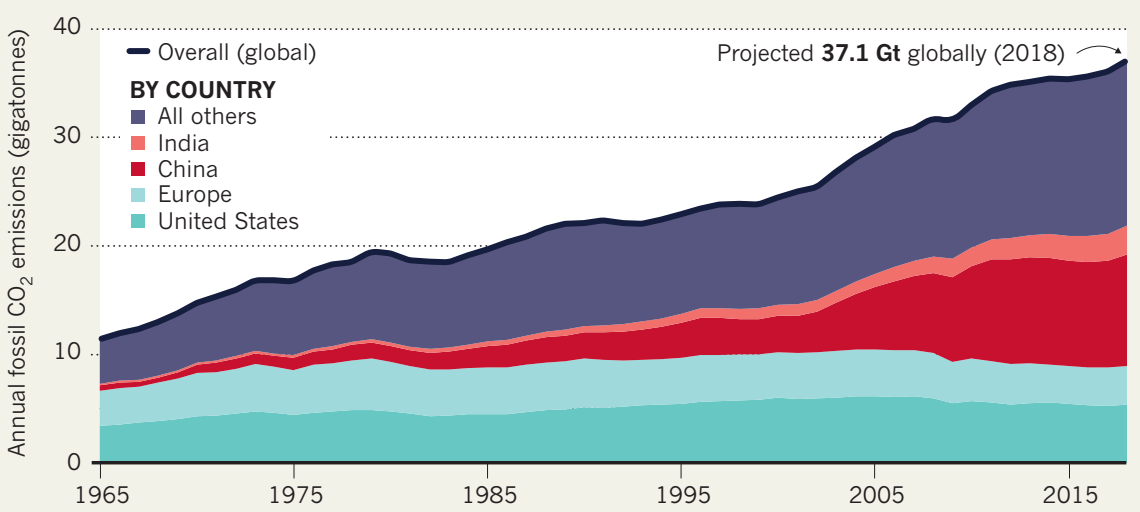

\section{RENEWABLES ARE PICKING UP}

Half of all new energy-generation capacity is renewable. Switching to electric cars would prioritize clean energy over oil.

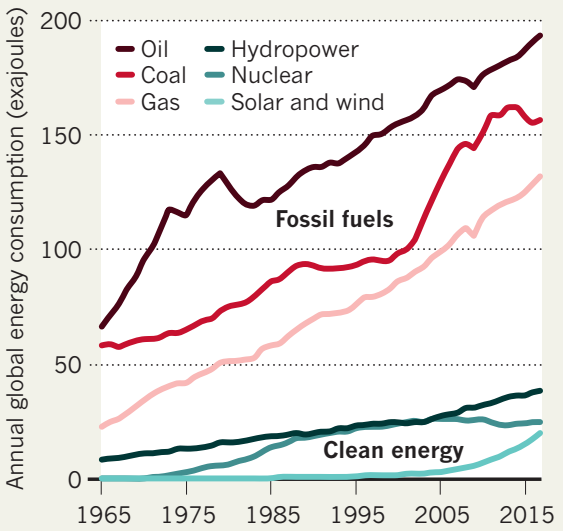

Canada, Mexico, Ethiopia and many in Europe, the coalition's members commit to developing long-term emissions-reduction strategies by 2020 .

\section{THE TASK AHEAD}

Rising emissions are of grave concern. But the low-carbon transition is snowballing, bowled along by the underlying economics. The task now for ministers and governments meeting in Katowice is to accelerate that momentum and keep everyone on board. This includes completing the rulebook for implementing the Paris agreement so that there is a clear path forward.

All efforts must strive to keep global warming to $1.5^{\circ} \mathrm{C}$. Now that we understand the different impacts of a $1.5^{\circ} \mathrm{C}$ and a $2^{\circ} \mathrm{C}$ rise, we cannot in good conscience provoke unnecessary risks to the most vulnerable and to the global economy.

First and foremost, the world must quickly replace coal and other fossil fuels with renewables. It is an economic imperative and an ecological necessity. No new investments

\section{SOLAR ENERGY IS AFFORDABLE}

Costs have dropped by $80 \%$ over the past decade as solar installations have expanded.

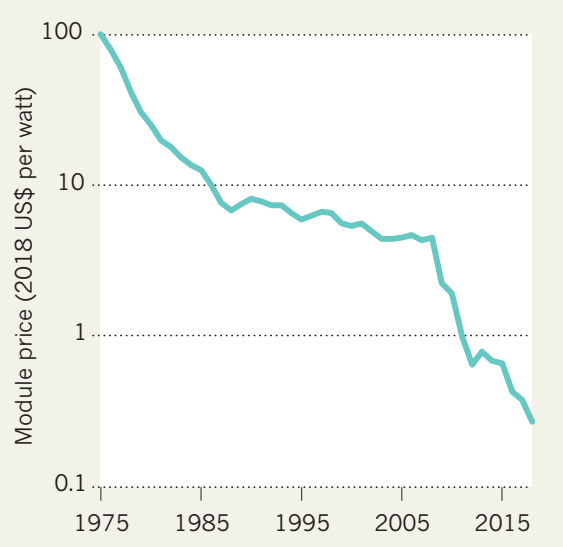

should be allocated to expanding fossil-fuel assets, and plans must be made for retiring existing infrastructure as clean technologies take hold.

Leaders must broaden the scope of their actions. The EU intends to ramp up its emissions-reduction goals to $55 \%$ by 2030 . This ambitious target can be attained by improving energy efficiency, by deploying renewables faster and by a quicker exit from coal. The EU can encourage stricter vehicle-emissions standards and hasten the uptake of electric vehicles, and develop public and shared transport. As one of the world's largest importers of commodities linked to deforestation (such as palm oil), the EU can develop an initiative to combat the loss of forests and other carbon sinks. This would build on a November statement from the French government, which aims to stop imports of non-sustainable forest or agricultural products by 2030 .

China can produce a low-emissions development strategy up to 2050, including a plan to replace coal that will ensure its emissions peak before 2030 and at a lower level 
than previously planned. China can also ensure that its investments made beyond its borders through the Belt and Road Initiative support renewable energy and protect and restore tropical forests and other sensitive ecosystems.

China and India have made substantial progress with reforestation and have the potential to do more: further tree planting could remove 1.25 gigatonnes and 520 megatonnes of $\mathrm{CO}_{2}$ per year in each country, respectively.

India can continue to deploy solar farms, leveraging its leadership of the International Solar Alliance to displace coal and clean up its smog-choked cities. By 2020, India can announce its own fossil-fuel exit strategy and a target date for its peak $\mathrm{CO}_{2}$ emissions.

A shared purpose across all political, civil and industrial sectors is key, as the breadth of authors and co-signatories to this article attests (see go.nature. com/2riswcr for co-signatories). What seemed radical in 2015 is now advantageous. Let us ensure that the exponential curve of solutions outpaces that of climate impacts, and drives net emissions to zero by 2050 . It's necessary, desirable and achievable. -

Christiana Figueres is convenor of Mission 2020 and vice-chair of the Global Covenant of Mayors. Corinne Le Quéré is director of the Tyndall Centre for Climate Change Research, University of East Anglia, Norwich, UK. Anand Mahindra is chair of the Mahindra Group, Mumbai, India. Oliver Bäte is chair of the board of management of Allianz SE, Munich, Germany. Gail Whiteman is professor and director of the Pentland Centre for Sustainability in Business, Lancaster University, Bailrigg, Lancaster, UK. Glen Peters is research director at the Center for International Climate Research, Oslo, Norway. Dabo Guan is chair professor in climate-change economics at the University of East Anglia, Norwich, UK, and distinguished professor at Tsinghua University, Beijing, China. e-mail:cfigueres@mission2020.global

1. Le Quéré, C. et al. Earth Syst. Sci. Data https:// doi.org/10.5194/essd-10-2141-2018 (2018).

2. Figueres, C. et al. Nature 546, 593-595 (2017)

3. Intergovernmental Panel on Climate Change. Global Warming of $1.5^{\circ} \mathrm{C}$ (IPCC, 2018).

4. Global Climate Action Summit. Exponential Climate Action Roadmap (Future Earth/Sitra, 2018).

5. Energy Transitions Commission. Mission Possible: Reaching Net-Zero Carbon Emissions from Harder-To-Abate Sectors by Mid-Century (ETC, 2018).

6. Yale Data-Driven Environmental Solutions Group. Who's Acting On Climate Change? Subnational and Non-State Global Climate Action (Yale Data-Driven, 2017).

A list of co-signatories accompanies this article online (see go.nature.com/2riswcr).

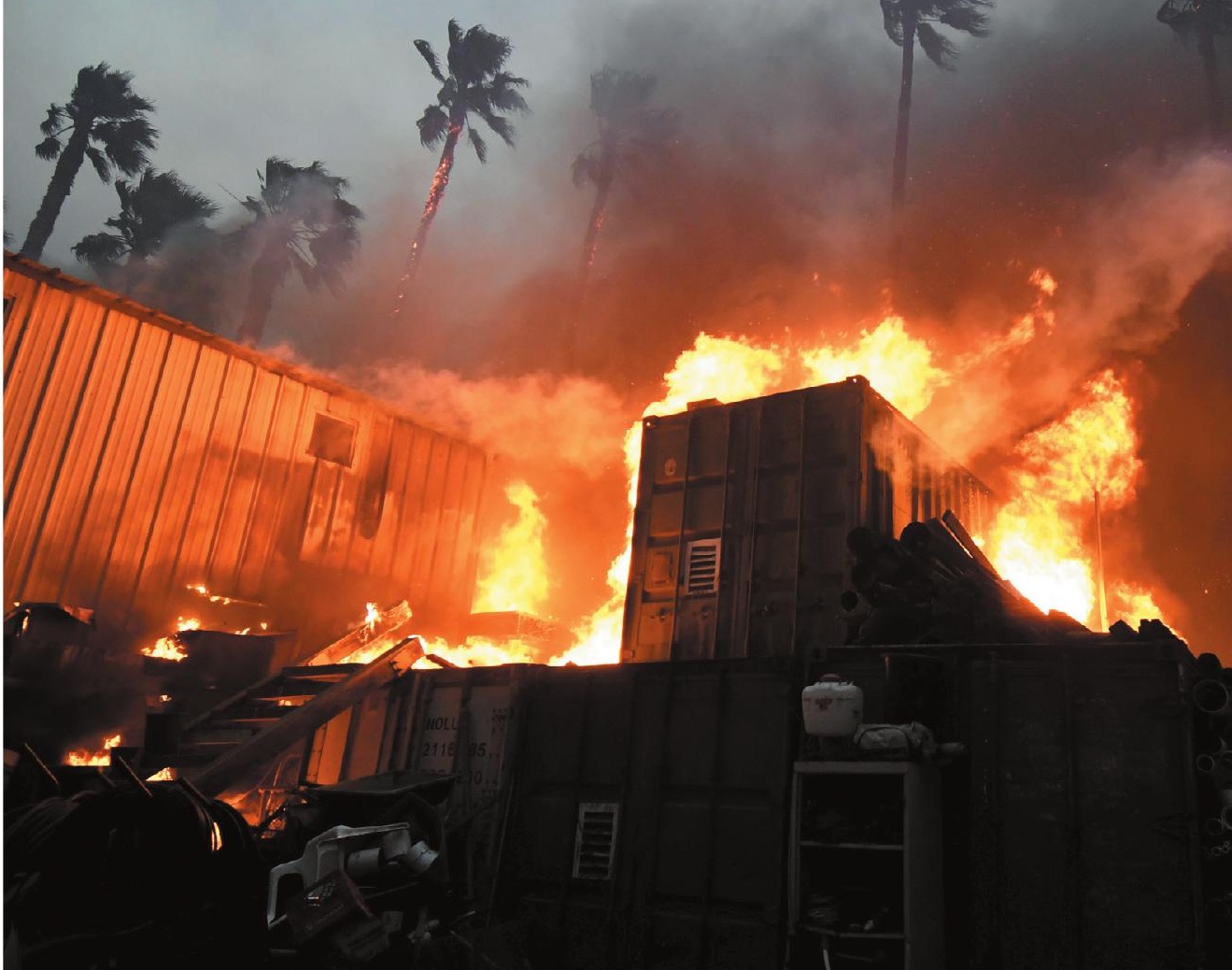

Devastating wildfires ravaged California last month.

\section{Global warming will happen faster than we think}

\section{Three trends will combine to hasten it, warn Yangyang $\mathrm{Xu}$, Veerabhadran Ramanathan and David G. Victor.}

$\mathrm{P}$ repare for the "new abnormal". That was what California Governor Jerry Brown told reporters last month, commenting on the deadly wildfires that have plagued the state this year. He's right. California's latest crisis builds on years of record-breaking droughts and heatwaves. The rest of the world, too, has had more than its fair share of extreme weather in 2018. The Lancet Countdown on health and climate change announced last week that 157 million more people were exposed to heatwave events in 2017, compared with 2000.

Such environmental disasters will only intensify. Governments, rightly, want to know what to do. Yet the climate-science community is struggling to offer useful answers.

In October, the Intergovernmental Panel on Climate Change (IPCC) released a report setting out why we must stop global warming at $1.5^{\circ} \mathrm{C}$ above pre-industrial levels, and how to do so ${ }^{1}$. It is grim reading. If the planet warms by $2{ }^{\circ} \mathrm{C}$ - the widely touted temperature limit in the 2015 Paris climate agreement - twice as many people will face water scarcity than if warming is limited to $1.5^{\circ} \mathrm{C}$. That extra warming will also expose more than 1.5 billion people to deadly heat extremes, and hundreds of millions of individuals to vector-borne diseases such as malaria, among other harms.

But the latest IPCC special report underplays another alarming fact: global warming is accelerating. Three trends - rising emissions, declining air pollution and natural climate cycles - will combine over the next 20 years to make climate change faster and more furious than anticipated. In our view, there's a good chance that we could breach the $1.5^{\circ} \mathrm{C}$ level by 2030 , not by 2040 as projected 